Biological and Clinical Sciences Research Journal

ISSN: 2708-2261

www.bcsrj.com

DOI: https://doi.org/10.54112/bcsri.v2020i1.35

Biol. Clin. Sci. Res. J., Volume, 2020: 35

Review Article

\title{
ROLE OF RHIZOBACTERIA IN PHYTOREMEDIATION OF HEAVY METALS
}

\author{
NADEEM $\mathbf{N}^{1}$, ASIF $\mathbf{R}^{1}$, AYYUB $S^{1}$, SALMAN $S^{2}$, SHAFIQUE $\mathbf{F}^{1},{ }^{*}$ ALI $Q^{1}$, MALIK $A^{1}$ \\ ${ }^{1}$ Institute of Molecular Biology and Biotechnology, The University of Lahore, Lahore, Pakistan \\ ${ }^{2}$ Department of Plant Breeding and Genetics, Faculty of Agriculture, Gomal University, DI Khan, Pakistan \\ *The first four authors; Nadeem N, Asif R, Ayyub S and Salman $S$ have equal contribution towards manuscript
}

*Corresponding author email: saim1692@gmail.com

(Received, $18^{\text {th }}$ July 2020, Revised $19^{\text {th }}$ October 2020, Published $27^{\text {th }}$ October 2020)

\begin{abstract}
Rhizobacteria, a plant growth promoting rhizobacteria $(P G P R)$ as beneficial microorganism which helps in defense from abiotic and abiotic stresses, colonizes in rhizosphere and played a major role in promoting plant growth and also provides enhance soil fertility. In the highly contaminated soil, the content of metal exceeds the limits of plant tolerance. It is also possible that treatment of plant with PGPR, here increasing the biomass of plant, stabilizing and the remediation of metal polluted soil. The use of rhizobacteria plays and important role in increasing the tolerance of plant towards toxic effects of heavy metals like arsenic, sulphur, mercury, chromium, cadmium, nickel, lead and copper etc. Heavy metal accumulation results in deterioration of soil fertility while PGPR helps to restore soil fertility. The process of phytoremediation has been proved to be the best way to remediate heavy metals from soil. The use of rhizobacteria with plants provides highly efficiency phytoremediation. However, there is still need to understanding the concept of microbial ecological study in rhizosphere and mechanism of detoxification of heavy metals form rhizosphere.
\end{abstract}

Keywords: rhizobacteria, heavy metals, plant growth promoting bacteria, phytoremediation, abiotic stress

\section{Introduction}

Heavy metals may be defined as elements which have metallic features like conductivity, ligand specificity, stability, etc. Metals have been present naturally in the soil with a lot of heavy metals ions accumulated in the form of compounds, or as simple ions and which are essential for plants as micronutrients (Rahmaty and Khara, 2011; Sharma et al., 2003; Tahir et al., 2020). Due to industrial revolution the pollution increased intensely by the toxic heavy metals due to human activities such as electroplating, fuel production, manufacturing and mining of metals, pesticide application etc (Almaroai et al., 2012; Arroyo et al., 2002; Babarinde et al., 2006). Metal pollution has become the most severe problem among the environmental problems nowadays (Cao et al., 2004; Khalil et al., 2020; Seregin et al., 2004; Zubair et al., 2016). Rhizobacteria is plant growth promoting (PGPR) beneficial microorganism which helps in defense from abiotic and abiotic stresses, colonizes in rhizosphere and played a major role in promoting plant growth and also provides enhance soil fertility (Lugtenberg and Kamilova, 2009; Vessey, 2003).

Rhizosphere bacterial species play an important role in phytoremediation from heavy metals in contaminated soil, through releasing of chelating agents heavy metals mobility affect the microbial population and also availability to plant, release of redox changes, phosphate solubilization, acidification and promote phytoremediation (Iqra et al., 2020; Lugtenberg and Kamilova, 2009; Mazhar et al., 2020b; Vessey, 2003). In phytoremediation process rhizobacteria metal adapted able to received extra attention. We need to increase our understanding about mechanisms involved in mobilization and transfer of heavy metals in the contaminated soils (Antoun, 2013). Soils which are polluted with heavy metals cause environmental problems the reason behind is the effects of metals which is highly toxic. There have options for sediments polluted due to metals and reclamation of soil is ex-situ and in-situ techniques (Bååth, 1989; Pamukcu and Kenneth Wittle, 1992; Ross, 1994). The in-situ aims for remediation from soil is that enhance the maintenance of metals either in soil particles. The other methods work on plants to reduce bioavailability or potential mobility of toxic metals from environment. The purpose of ex-situ techniques is that separating and extracting of metals from the soil over series of biological, physical and chemical methods with the help of specifically designed reactor (Dixit et al., 2015; Jansen et al., 1994; Nouri et al., 2009).

[Citation: Nadeem, N., Asif, R., Ayyub, S., Salman, S., Shafique, F., Ali, Q., and Malik, A. (2020). Role of rhizobacteria in phytoremediation of heavy metals. Biol. Clin. Sci. Res. J., 2020: 35. doi: https://doi.org/10.54112/bcsri.v2020i1.35] 
Phytoremediation method offers detoxification and removal of contaminants which involved the use of plants to sequester and it is very effective, ecologically gentle, less expensive and also a socially standard technology specifically for pollution elimination (Memon et al., 2001; Schröder et al., 2008). Phytoremediation depends upon the tolerance and ability of plant to accumulate HMs (high concentrations) and also to obtain yield from a large plant biomass (LeDuc and Terry, 2005; Mench et al., 2009). Heavy metals mostly biologically nondegradable but persist indefinitely mostly in under developed and developed countries as contaminations in the environment. Presence of heavy metals in plants harshly effects on growth and crop yield, symbiosis due to high concentrations of heavy metals (Felix, 1997; Giordano et al., 1975; Grytsyuk et al., 2006). The heavy metals are harmful for soil because the heavy metals cannot be degraded biologically but it is likely to transfer from one oxidation state to the alternative state which is less toxic form of the compound (Chu and Wong, 1987; Schmidt, 2003). Degrading capacity of rhizobacteria has been increased the spectrum by using or introducing new techniques such as genetic engineering. phytohormones major chemical which are involved in the uptake of metal. Rhizobacteria plays very important role in phytoremediation and also release essential hormones for plant growth (Garrido et al., 2005; Prasad et al., 2011).

The heavy metal stress caused important impact on plants that's why the plants have to avoid it through some of the mechanisms such as.

1. At root surface metal ion adsorbed.

2. Root cells transversely membrane metals ions help to move into the root cells.

3. In vacuole metal ion immobilized in small proportion.

4. Movement of the metal intracellularly through the vascular tissue of root

5. The accumulation of metallic ions through the root-to-shoot transfer and also from leave tissue.

Mobilization and immobilization of the heavy metals is one of the important roles of rhizobacteria which provide tolerance to heavy metals. Soil pollution is the significant and serious environmental problem and cause negative effect on agriculture as well as also on human health (Gadd, 2000; Lahori et al., 2017; Unz and Shuttleworth, 1996). The significant interface of plant and soil is rhizobacteria, which plays vital role in the phytoremediation of polluted soils through remediating the heavy metals. Extreme gathering of the heavy metals in several plants species has been found highly toxic (Grytsyuk et al., 2006; Krantev et al., 2008; Lahori et al., 2017). Presence of heavy metal ions at high level in the atmosphere absorbed from root and transferred to the shoot which effect on plant growth and reduced metabolism. Contamination of soil and water due to heavy metals is also a major problem. Moreover, high concentrations of metal in the soil have become the reason of many problems such as decrease in soil fertility, microbial action and also effect on yield production (Henning et al., 2001; Iqra et al., 2020; Ma et al., 2003). Cadmium is a toxic and nonessential heavy metal which is able to reveal the problem and also inhibits shoot and root growth, nutrient uptake disturbs and accumulated rate of important crops. The crop plants which are usually rich in Cadmium and consumed by human and animals causes many harmful diseases. On the other hand, if $\mathrm{Cd}$ concentration not controlled then the overtime soil may be ultimately become unstable for the production of crop plants (Das et al., 1997; Hasan et al., 2009; Hou et al., 2007). Heavy metals cause contamination in environment treated by conventional technologies which is based on the physicochemical principles but these technologies are uneconomic and inefficient. On the other hand, removal of metals from aqueous solution is carried with the addition of reagents in the solution which increase the $\mathrm{pH}$ and soluble form of metals converts into the insoluble form which causes precipitation in the solution (Cuypers et al., 2011; Martelli et al., 2006; Nagajyoti et al., 2010).

\section{Interactions of rhizobacteria}

\section{Interaction between plant and bacteria}

Root zone of plants colonize with dense population of microorganisms. Rhizosphere is very attractive habitat as compare to bulk soil, organic carbon which is gained from the plant roots (Etesami, 2018; Van Loon, 2007). In Rhizosphere more than $85 \%$ organic carbon can be originated from the tissues and sloughed off the root cells. Relationship between plant and bacteria is always naturally symbiotic in this interaction both of them get benefit from each other. In this relationship roots of plants are mainly involved to give benefit to the bacteria (Antoun and Prévost, 2005; Chen et al., 2000; Persello-Cartieaux et al., 2003). Similarly, bacteria help plant in the maintenance of nutrient supply in and in recycling process. Rhizobacteria also maintain soil fertility and also detoxified harmful chemicals which usually released due to toxicity of heavy metals. Plants provide carbon source to the bacteria which reduce phytotoxicity (Requena et al., 1997; Zahran, 1999).

Plant bacteria interaction with respect to soil

[Citation: Nadeem, N., Asif, R., Ayyub, S., Salman, S., Shafique, F., Ali, Q., and Malik, A. (2020). Role of rhizobacteria in phytoremediation of heavy metals. Biol. Clin. Sci. Res. J., 2020: 35. doi: https://doi.org/10.54112/bcsrj.v2020i1.35] 
Composition of root and soil conditions plays an important role in the interactions with respect to specificity. Rhizobacteria called as soil tolerated bacteria because it inhibiting rhizosphere. Some of the bacterial species also colonized around the surroundings and to the surface of root such as the endobacteria (Barea et al., 2005; Nadeem et al., 2014; Requena et al., 2001). The interaction can be specific as well as non-specific. Toxic metal inhibits the growth of plant but other factors like water, lowsoil fertility, beneficial nutrients, harsh and dry conditions may also be responsible for the inhibition of plant growth (Bhattacharyya and Jha, 2012; Haas and Défago, 2005).

\section{Removal of heavy metals and PGPR interaction}

The removal of heavy metals is very important due to their toxicity. Release of phosphate solubilization, acidification process, chelating agents and redox changes enhance the potential of phytoremediation. There is a need to progress understanding about mechanisms which are involved in the mobilization and also in the transfer of heavy metal so, we can be able to reduce the heavy metals from soil (de Oliveira Mendes et al., 2014; Goldstein, 1995; Halder and Chakrabartty, 1993; Khan et al., 2009). Heavy metals disturb the metabolic processes of plant and animals. Interaction of bacteria with plant affected from these following conditions which are very important for plant and bacteria.

1. Improper supply of water.

2. Harsh climate changes.

3. Deficiency of soil fertility.

4. Lack of nutrients.

\section{Heavy metals effect on plants}

For plant uptake heavy metals present in the soil as soluble components. Some heavy metals require for growth of plant and also for maintenance but if those metals present in high range than it become toxic for plant (Dubey, 2010; McIntyre, 2003; Reichman, 2002). And cause cytoplasmic enzymes inhibition due to oxidative stress damage cell structures. If heavy metals cannot remove from plant than ultimately plant died due to its toxic effects. Copper is important metal for development and growth of plant. The plant growth promoting rhizobacteria (PGPR) are beneficial for the plants and helps to reduce the toxicity level. The higher concentration and long term presence of heavy metals plant become chloric and cause deficiency of iron (Khalid et al., 2015; Sayyed et al., 2013; Tank and Saraf, 2009).

\section{Mechanism}

\section{Rhizobacteria secretions}

Rhizobacteria secretion could play a key role for phytoremediation which is assisted by rhizobacteria.
Direct mechanism contains nitrogen fixation synthesis of siderophores or indirect mechanism contains inhibiting phytopathogens from plant growth then development (Kloepper et al., 1980; Van Loon et al., 1998). The microbes promote the plant growth under stress conditions and help in degradation of contaminants. The PGPR has been mostly used for an extensive period assisting plant to uptake large amount of nutrients from soil or preventing plant diseases (Glick, 2012; Saharan and Nehra, 2011; Schippers et al., 1987). PGPR application has been prolonged to bioremediation of organic metal pollutants. Rhizobacteria create metal chelating agents called siderophores and some heavy metals they have main part in acquisition. Organic matters have the result of scavenging $\mathrm{Fe}^{3+}$ increase the bioavailability of soil bound iron (Falkowski and Raven, 2013; Hughes and Poole, 1989; Schroth and Hancock, 1982). Lived in the metal polluted soils are often iron deficient in plant growth, the microbial siderophore are used in iron chelating agents they set the accessibility of iron in the plant rhizosphere (Bruins et al., 2000; Gavrilescu, 2004; Raffi et al., 2010). The plants required minor iron concentrations for the normal growth than do microbes but binding affinity of Phyto siderophores for iron is less than affinity of microbial siderophores. Root growth stimulated by different species of plants and has 1aminocyclopropane-1-carboxylate (ACC) deaminase enzymes which control the amount of ACC by decreasing or hydrolyzing and ethylene a plant hormone precursor biosynthesis of plant by ethylene (Hontzeas et al., 2006; Ma et al., 2003; Madhaiyan et al., 2007). Removal of ACC from seeds or roots is taken up through the bacteria and cleaved by ACC deaminase to ammonia. The inner and outer level ACC the plant need exude increase amount of ACC (Jia et al., 2000; Nascimento et al., 2014).

\section{Transform toxic heavy metals}

The decrease in growth due to heavy metals among $25 \%$ to $40 \%$ depending on the type of metal both in root tissue as well as shoot when plants have ability to create a very significant diminution of accumulation for heavy metals particularly in the plant roots while than $50 \%$ decrease in addition of $\mathrm{Cd}, \mathrm{Pb}$ and $\mathrm{Zn}$ in the roots (Hansda et al., 2014; Mushtaq et al., 2020; Saleem et al., 2007; Singh et al., 2019). The bioavailability of metals in soil to plant is also influenced the phytoremediation to productivity of plant. Bacteria can convert toxic heavy metals to form that are additional readily taken up into plant roots. Bacteria can increase the concentration of Selenium and organ selenium forms such as Smet are known to be taken at faster rates

[Citation: Nadeem, N., Asif, R., Ayyub, S., Salman, S., Shafique, F., Ali, Q., and Malik, A. (2020). Role of rhizobacteria in phytoremediation of heavy metals. Biol. Clin. Sci. Res. J., 2020: 35. doi: https://doi.org/10.54112/bcsrj.v2020i1.35] 
(Khan and Bano, 2018; Ojuederie and Babalola, 2017). The comparative change of organic bound with $\mathrm{Cu}, \mathrm{Pb}$ and $\mathrm{Zn}$ were separately $+5 \%+3 \%$ and $+23 \%$ while in the infected rhizosphere $0.8 \%,-2 \%$ and $-3 \%$ in the non-infected rhizosphere respectively. So, a huge amount of $\mathrm{Cu}, \mathrm{Zn}$ and $\mathrm{Pb}$ bounded by organic matter in the infected rhizosphere (Abbaszadeh-Dahaji et al., 2016; Guarino et al., 2020). Chemical properties like $\mathrm{pH}$ of organic matter are directly affected the metal bioavailability through moving their soil rhizobacteria. The Pseudomonas melophilia reduced the mobile and toxic $\mathrm{Cr}^{3+}$ into nontoxic $\mathrm{Cr}^{6+}$ and also to reduce environmental mobility for additional toxic ions $\mathrm{Hg}^{2+}, \mathrm{Pb}^{2+}$ (Jeevanantham et al., 2019; Li et al., 2019).

\section{Inhibition of plant pathogens}

PGPR provides different ways to suppress plant viruses. It involves the competition of nutrients and an anti-bacterial environment for the manufacture of antibiotics and the production of siderophores that reduce the availability of the iron needed for bacterial growth (Glick and Stearns, 2011; Ma et al., 2011; Tak et al., 2013). Another mechanism similar to the production of lytic enzymes B-1,3-glucanases and chitinases plays a vital role in the reduction of glucan and chitin in the fungal cell wall. PGPR showed resistance to heavy metal during phytoremediation process. It has been shown that inoculating plants with plant growth that promotes rhizobacteria or by treating microbes with plant microscopic plantings may be effective in promoting plant growth (He and Yang, 2007; Kong and Glick, 2017; Nie et al., 2002).

\section{Stimulation of transport protein}

Transport protein participating in the passage of ions. The protein might support in the change of substances by means of facilitated diffusion. Plants flourishing in tiny pots are usually considerably smaller than those expanding in large, at the same time when they have superficially suitable sources of water and nutrients (Salt et al., 1998; Singh et al., 2003; Zhao and McGrath, 2009). Bacteria persistence and propagation in the atmosphere furthermore within numerous hosts are censoriously reliant on the uptake and appropriation of conversion metals like zinc, iron, and manganese. For instance, cells might rigorously standardize intracellular zinc concentration while the elevated concentration of zinc is always noxious for cellular purpose which developed numerous types of protein implicated in attachment and transfer of zinc ions (Hall, 2002; Pilon-Smits, 2005; Wuana and Okieimen, 2011). The bacteria might also accelerate sulfate move proteins placed in the root cell or plasma membrane which similarly stimulates selenite mineral. The inorganic
$\mathrm{Hg}$ absorbance elevated in plants has not been correctly inspected but has been associated to the inactive acceptance of lipophilic chloride facilities in phytoplankton (Hutchinson, 1973; Thomas et al., 1980).

Speciation versus bioavailable of heavy metal in soils

Soil rhizobacteria can also directly affect the melting of iron by altering the specificity of heavy metals in rhizosphere. The mycorrhiza played an important role in iron deficiency from the rhizosphere and it has impact on increasing plant tolerance in trapping heavy metals from soil (Li et al., 2015; Marschener, 1998; Watteau and Berthelin, 1990). Although high heavy metal concentration is usually harmful to microbial physiological aspects, therefore the tracking of heavy metals amount and number of different heavy metals is very necessary for the normal bacterial growth for reducing redox and cellular activity. Bacterial interactions with heavy metals depend on metal forms and the availability of bioavailability (González-Guerrero et al., 2016; Xie and Tang, 2019). The interaction of plant bacteria can promote the production of chemicals that can alter the chemical properties of the soil in rhizosphere and improved the accumulation of heavy metals in the plants body. The availability of bioavailability depends on a variety of factors such as soil $\mathrm{pH}$, cation exchange rate, soil content of organic matter, mineral and iron content, water and heat content, biological properties of soil, chemical properties of metals and microbial activities under soil and climate conditions. In addition, the availability for heavy metal ions increases under low anaerobic oxidizing $\mathrm{pH}$ condition (Joshi and Juwarkar, 2009; Marsh Jr et al., 1963; Ullah et al., 2015).

PGPB mechanisms to control heavy metals stress The heavy metals cannot be decomposed which can be harmless to bacteria. A few microorganisms have evolved to develop ways of removing toxins from the towards combat the harmless effects of these inanimate metals (Sgroy et al., 2009). Heavy metals such as $\mathrm{Al}, \mathrm{Pb}, \mathrm{Cd}$, do not production any role in nature and are harmless to living organisms. There are several ways to protect against heavy metal resistance by microbial cells. These processes are the outer barrier of cells, the outer division of cells, and the active transport of metallic ions, the inner cell structure, and the reduction of metallic ions (Ahemad, 2019; Begum et al., 2019). Metal filtration that exceeds biological requirements prevents the growth of bacteria or bacteria that react to high levels of metals through various forms of resistance against heavy metal toxicity. Bacterium which increase the

[Citation: Nadeem, N., Asif, R., Ayyub, S., Salman, S., Shafique, F., Ali, Q., and Malik, A. (2020). Role of rhizobacteria in phytoremediation of heavy metals. Biol. Clin. Sci. Res. J., 2020: $35 . \quad$ doi: https://doi.org/10.54112/bcsrj.v2020i1.35] 
growth of plants such as Rhizobium, Brad rhizobium and Pseudomonas have been exposed to $\mathrm{Co}^{2+}, \mathrm{Cu}^{2+}$, $\mathrm{Zn}^{2+}, \mathrm{Mn}^{2+}, \mathrm{Fe}^{2+}, \mathrm{Mo}^{2+}$ and the sensitivity of these metals has been tested in vivo which has shown that Rhizobium legumin Sarum spots are very sensitive to $\mathrm{Cu}^{2+}$ and $\mathrm{Co}^{2+}$ as compare with rhizobium (Islam et al., 2016; Rajkumar and Freitas, 2008). This flexible metal resistance method was tested by examining the areas exposed to anthropogenic or natural metal contamination for a long time. Acquisition of heavy metals by microorganisms occurs by bioaccumulation which is an active process or by adsorption which is a synthetic process (Bashan and De-Bashan, 2010; Dodd et al., 2010; El-Meihy et al., 2019). Many micro-organisms such as fungi, bacteria and algae have been used to clean contaminating areas by heavy metals. Bacteria use two types of heavy ion detection methods. The initial mechanism of chemiosmosis gradient throughout the cytoplasmic membrane is rapid and undetectable. Another method is a specific substrate, which slows down and undergoes ATP hydrolysis. The most important methods are physical isolation, exclusion and difficulty (Bunow, 1978; Lane et al., 2010; Silver and Phung, 2005; Taj and Rajkumar, 2016).

When heavy metals attached to the extracellular cell material, they can immobilize metals and blockage of its intake with the help of bacterium cells. On the cell surface, most of metals bind to the functional group that is anionic. By forming the effective barrier around the cell, heavy metals bind to extracellular polymers i-e proteins, polysaccharide etc. which helps to detoxify them. Siderophores minimize the bioavailability of metal here performs the toxicity reducing. Specific production metabolites result in precipitation of heavy metals (Ahemad, 2015; Pajuelo et al., 2011; Sher and Rehman, 2019; Zubair et al., 2016). Different types of bacteria manifest efflux for the transporters with higher level of substrate affinities because of which they can expel toxic metals with high concentrations which expelled outside of the cell. The plasmid encoded energy dependent system which involves chemiosmosis ion pumps. Along with the ATPase that are reported for acceptance of cadmium and chromium (De la Torre et al., 1999; Lakra et al., 2006; Pratap and Bonga, 1993). There is another method for toxicity of heavy metals in which ions may be converted into innocuous form which follow the entry into bacterial cells. This whole mechanism is known as mechanism of cytosolic sequestration. This allows the uptake of heavy metals with high concentration; for instance, metallothionein's synthesis. They have low molecular weight. The metal binding protein that is cysteine has high metal affinity e.g., copper, cadmium, silver and the mercury (Canli et al., 2001; Tanwir et al., 2015; Tiwari et al., 2009). As an alternative, some of the bacteria utilize methylation method that involves the methyl group which is transferred to the metal and metalloids. There is a limitation that only a few metals can be methylated. There is also a method used for the toxicity of heavy metals is decontamination of soil which involved the heavy metals reduction (Bordajandi et al., 2004; Karadede-Akin and Ünlü, 2007). The species of bacteria responsible for the reduction of heavy metals referred as dissimulator of metal reducing bacterium. Those bacterial strains help in detoxification of chromium which involves the reduction of $\mathrm{Cr}$ by the strains of bacteria which plays a significant role in the acquisition of severely heavy metals (Liu et al., 2006; Viti et al., 2003; Wang and Shen, 1995).

Significance of rhizobacteria in phytoremediation For improving the growth of plant e.g., wheat, we have to screen PGPR. The study has suggested that the potential for biosynthesis of auxin through rhizobacteria which could be used as a tool for screening the effective PGPR strains (Deshwal and Kumar, 2013; Wani et al., 2009). A new combination of in vitro screening method which include microplate assay with plant i-e strawberry seedling to test the PGP strain which have more efficient potential biological controlling agents which has been developed successfully. To screen the effective PGPR strain ACC deaminase trait could be used as an efficient tool. It could be successfully used as biofertilizers which increase the growth of inoculated plants (Mazhar et al., 2020a; Wani et al., 2015). In the soil, the high levels of heavy metals decrease the microbial activity and it affects the production of crop by getting accumulated in plant organs. Metal ions are present in the soil and these are absorbed by the roots which transported to various plant organs. The enzymes and proteins in the cells which have higher affinity of heavy metals they rendered them inactive and also lost their function (Hansda et al., 2014; Liu et al., 2015). When they interact with heavy metals the structure of protein change and affect the plant growth by photo-system inactivation. At the end the free radicals produced oxidative effect that has adverse effect on biochemical and the physiological processes of plants. Reduction in growth and also development happens due to the disturbance in photosynthetic and also respiratory mechanism (Chaudhary and Khan, 2018; Qi et al., 2018; Tirry et al., 2018). The mechanism of PGPB to overcome the metallic stress, bacteria including the PGPB have several resistance mechanisms they can

[Citation: Nadeem, N., Asif, R., Ayyub, S., Salman, S., Shafique, F., Ali, Q., and Malik, A. (2020). Role of rhizobacteria in phytoremediation of heavy metals. Biol. Clin. Sci. Res. J., 2020: 35. doi: https://doi.org/10.54112/bcsrj.v2020i1.35] 
be immobilize, transform the metals, as well as reducing the toxicity which tolerate the uptake of heavy metal ions. PGP Bacteria help the plants to grow and these bacteria grow in soil or on the roots of plant. Pant will grow by helping the certain nutrients, modulating the hormone levels of plant and also protecting the plant from any type of pathogen (Saharan and Nehra, 2011; Zhu et al., 2015).

The quality of bacteria that respond to heavy metals plays an important role in utilization for bioremediation of accumulation of toxic metals in plants. In agronomic processes, these bacteria express the unique ability of metal detoxification along with the growth promoting agent's property (Ayangbenro and Babalola, 2017; Zaidi et al., 2009). Researchers had reported many applications of bacteria i.e., sphingomonas macrogoldabidus, micro bacterium lique-faciens and the micro bacterium arabinogalactanolyticum inoculated to the plants; the Amurale which gives significant results by increased of Ni-uptake by plants as compared to the untreated plants. Carrillo-Castaneda reported that the potential of PGP in the protection of alfalfa (Medicago sativa) seeds from the accumulated copper due to the absorption by the roots to the shoots in the seedlings of these plants (Silver and Phung, 2005; Vacheron et al., 2013). It has been reported that Hydroxamate siderophores shown that besides the presence of heavy metals which increase the iron uptake by plants. Iron is the essential micro-nutrients for plants and also for microbes. Under anaerobic conditions such as flooded soil, high concentration of $\mathrm{Fe}^{2+}$ ions which are generated through reduction of $\mathrm{Fe}^{3+}$ ions and due to excessive uptake of iron leads to iron toxicity for plant cells. In aerobic conditions solubility of iron is low here limiting the supply of iron for different forms of life (Van Loon, 2007; Watteau and Berthelin, 1990). Bacteria can overcome the limitation of nutritional iron by using the chelatoragentsis known as siderophores. Through various ways the PGPB play a beneficial role in the growth of plant. For example, from PGPB siderophores prevent some pathogens from sufficient amount of iron hereby limiting the ability to proliferate. Nitrogen fixation is another important role of PGPB in the field of biology. Under the conditions of low soil moisture, the rhizobia are sensitive to drought stress resulting the decrease in nitrogen fixation. These studies gave an insight to the role PGPB, under the heavy metals stress increasing the biomass of plants (Saleem et al., 2007; Salt et al., 1998; Sayyed et al., 2013).

Transformation and the uptake of heavy metals
The mechanisms which are involved in transformation of metal ions in soil leads to wards the loss of heavy metals (uptake of plant, leaching and the volatilization reactions). The most of the metals do not undergo the volatilization related losses. Actually, the fate of metalloids in soil totally depends upon its properties and its environmental factors (Khan and Bano, 2018; Marschener, 1998; Ross, 1994). The availability and the mobility of metals in soil affected by microbes and they can be done through certain steps, acidification, changes of redox, production of iron chelators and the siderophores, mobilizing the metal phosphates. Actually the heavy metal in soil which are bound to both organic and inorganic substances or these are present as insoluble precipitates that are not available for root uptake, siderophores of bacteria produce (Sayyed et al., 2013) PGPB which have the ability to solubilize the heavy metals having $\mathrm{Fe}$ and make them available for roots of plants to take up. These PGPR helps to reduce the metals toxicity by bio-sorption method because of the bacterial cells absorb high amount of heavy metals. The environmental factors that affect the growth of plant include water, light, and the temperature, nutrition and also humidity. Soil hardness affects the growth of roots (Gadd, 2000; Haas and Défago, 2005; Khan and Bano, 2018).

\section{Approach by genetically engineered}

Various genetically engineered approaches have been developed and these are used to optimize the enzymes, organisms that are relevant for biodegradation, and also metabolic pathways. With the molecular method allow the characterization of structure of microbial community and the activities. There are a large number of proteins which bind to different heavy metals with whole range with greater affinity (Saharan and Nehra, 2011; Vessey, 2003; Zaidi et al., 2009). The metal binding proteins are at the outer membranes in plants and microbes where they will interact with metal ions in environment here ensuring the transport of metal ions to cytosol. And by the metal-cochaperones these are transferred to suitable receptor proteins. Plants respond high levels of heavy metals by synthesizing (Abbaszadeh-Dahaji et al., 2016; Ayangbenro and Babalola, 2017). Heavy metals are being accumulated in soil through sewage disposal and the industrial wastes. Among various traditional soil remediation technologies phytoremediation use to clean up the metal contaminated sites has increasing the attention as cofriendly as well as inexpensive. Improvement of metal accretion plants traits like genetic engineering necessary perspectives of certain many biological processes implemented in it by roots from the soil sap

[Citation: Nadeem, N., Asif, R., Ayyub, S., Salman, S., Shafique, F., Ali, Q., and Malik, A. (2020). Role of rhizobacteria in phytoremediation of heavy metals. Biol. Clin. Sci. Res. J., 2020: 35. doi: https://doi.org/10.54112/bcsrj.v2020i1.35] 
and then transferred to shoots. Metal contaminated soil by phytoremediation can be done by different forms of genetically engineered rhizobacteria (Canli et al., 2001; Dodd et al., 2010; Joshi and Juwarkar, 2009). Phytoremediation is an eco-friendly and the emerging technology that has gained the wide acceptance by, any regulatory authorities. Its use is limited time taken to achieve the clean-up goal (Cuypers et al., 2011; Lahori et al., 2017; Li et al., 2015). Currently it is the area of the active research in plant biology. Number of metal accumulated by plants has been identified as the potential candidates to Phytoremediate the metal polluted soil. Various types of strategies have been applied to generate the plants that are help to grow in environmental conditions and to transfer the number of metals (Dubey, 2010; Halder and Chakrabartty, 1993). The use of genetic engineering helps to modify the plant for enhanced efficacy of phytoremediation strategies. Plants are involved in this process and there are many chances of food chain being distributed.

\section{Conclusion}

When evaluating the rhizobacteria effects in phytoremediation of toxic metals from contaminated soil, the process carried out both by bacteria and plants while to protect plants from heavy metaltoxicity. Certain bacteria use special developmental processes for phytoremediation of heavy metals. Scientist are working to access the role of PGPR but still not understanding the concept of phytoremediation. There are of few questions which needs to be answered yet,

1. There is need to investigate the microbes induced changes in rhizosphere of plant related to accumulation of metal, and also the contaminated soil.

2. There is need to quantify the effect of phytoremediation process on phytoavailability of heavy metals.

3. There is need to examine the accumulation and the distribution of toxic metals.

4. The role played by the bacteria from solution of soil in plant and the uptake of cadmium is poorly understood yet.

5. There is need to understand the mobilization and the transfer of metals. Here we develop the strategies and the optimization of phytoextraction process. There is more need to understand the role of soil rhizobacteria for phytoremediation.

\section{Conflict of interest}

The authors declared absence of any conflict of interest.

References
Abbaszadeh-Dahaji, P., Omidvari, M., and Ghorbanpour, M. (2016). Increasing phytoremediation efficiency of heavy metalcontaminated soil using PGPR for sustainable agriculture. In "Plant-Microbe Interaction: An Approach to Sustainable Agriculture", pp. 187-204. Springer.

Ahemad, M. (2015). Phosphate-solubilizing bacteriaassisted phytoremediation of metalliferous soils: a review. 3 Biotech 5, 111-121.

Ahemad, M. (2019). Remediation of metalliferous soils through the heavy metal resistant plant growth promoting bacteria: paradigms and prospects. Arabian Journal of Chemistry 12, 1365-1377.

Almaroai, Y. A., Usman, A. R., Ahmad, M., Kim, K.-R., Moon, D. H., Lee, S. S., and Ok, Y. S. (2012). Effects of synthetic chelators and lowmolecular-weight organic acids on chromium, copper, and arsenic uptake and translocation in maize (Zea mays L.). Soil Science 177, 655663.

Antoun, H. (2013). Plant-growth-promoting rhizobacteria. Brenner's Encyclopedia of Genetics, 2nd edition, Volume 5.

Antoun, H., and Prévost, D. (2005). Ecology of plant growth promoting rhizobacteria. In "PGPR: Biocontrol and biofertilization", pp. 1-38. Springer.

Arroyo, M. d. M. D., Cots, M. Á. P., HORNEDO, R. M. D. I., Rodríguez, E. M. B., Beringola, L. B., and Sánchez, J. V. M. (2002). Sewage sludge compost fertilizer effect on maize yield and soil heavy metal concentration. Revista internacional de contaminación ambiental $\mathbf{1 8}$, 147-150.

Ayangbenro, A. S., and Babalola, O. O. (2017). A new strategy for heavy metal polluted environments: a review of microbial biosorbents. International journal of environmental research and public health 14, 94.

Bååth, E. (1989). Effects of heavy metals in soil on microbial processes and populations (a review). Water, Air, and Soil Pollution 47, 335-379.

Babarinde, N. A., Babalola, J. O., and Sanni, R. A. (2006). Biosorption of lead ions from aqueous solution by maize leaf. International Journal of Physical Sciences 1, 23-26.

Barea, J.-M., Pozo, M. J., Azcon, R., and AzconAguilar, C. (2005). Microbial co-operation in the rhizosphere. Journal of experimental botany 56, 1761-1778.

[Citation: Nadeem, N., Asif, R., Ayyub, S., Salman, S., Shafique, F., Ali, Q., and Malik, A. (2020). Role of rhizobacteria in phytoremediation of heavy metals. Biol. Clin. Sci. Res. J., 2020: 35. doi: https://doi.org/10.54112/bcsrj.v2020i1.35] 
Bashan, Y., and De-Bashan, L. E. (2010). How the plant growth-promoting bacterium Azospirillum promotes plant growth-a critical assessment. In "Advances in agronomy", Vol. 108, pp. 77-136. Elsevier.

Begum, N., Hu, Z., Cai, Q., and Lou, L. (2019). Influence of PGPB inoculation on HSP70 and HMA3 gene expression in switchgrass under cadmium stress. Plants 8, 504.

Bhattacharyya, P. N., and Jha, D. K. (2012). Plant growth-promoting rhizobacteria (PGPR): emergence in agriculture. World Journal of Microbiology and Biotechnology 28, 13271350.

Bordajandi, L. R., Gómez, G., Abad, E., Rivera, J., Fernández-Bastón, M. d. M., Blasco, J., and González, M. J. (2004). Survey of persistent organochlorine contaminants (PCBs, PCDD/Fs, and PAHs), heavy metals ( $\mathrm{Cu}, \mathrm{Cd}$, $\mathrm{Zn}, \mathrm{Pb}$, and $\mathrm{Hg}$ ), and arsenic in food samples from Huelva (Spain): levels and health implications. Journal of Agricultural and Food Chemistry 52, 992-1001.

Bruins, M. R., Kapil, S., and Oehme, F. W. (2000). Microbial resistance to metals in the environment. Ecotoxicology and environmental safety 45, 198-207.

Bunow, B. (1978). Chemical reactions and membranes: A macroscopic basis for facilitated transport, chemiosmosis and active Transport part I: Linear analysis. Journal of theoretical biology 75, 51-78.

Canli, M., Kalay, M., and Ay, Ö. (2001). Metal (Cd, $\mathrm{Pb}, \mathrm{Cu}, \mathrm{Zn}, \mathrm{Fe}, \mathrm{Cr}, \mathrm{Ni}$ ) concentrations in tissues of a fish Sardina pilchardus and a prawn Peaenus japonicus from three stations on the Mediterranean Sea. Bulletin of environmental contamination and toxicology 67, 75-82.

Cao, Y., Huang, R., Jiang, W., and Cao, Z. (2004). Effect of heavy metal lead and cadmium on grain quality of maize. Yournal of Shenyang Agricultural University 36, 218-220.

Chaudhary, K., and Khan, S. (2018). Role of plant growth promoting bacteria (PGPB) for bioremediation of heavy metals: an overview. In "Biostimulation Remediation Technologies for Groundwater Contaminants", pp. 104-125. IGI Global.

Chen, C., Belanger, R. R., Benhamou, N., and Paulitz, T. C. (2000). Defense enzymes induced in cucumber roots by treatment with plant growth-promoting rhizobacteria (PGPR) and Pythium aphanidermatum. Physiological and molecular plant pathology 56, 13-23.

Chu, L., and Wong, M. H. (1987). Heavy metal contents of vegetable crops treated with refuse compost and sewage sludge. Plant and soil 103, 191-197.

Cuypers, A., Karen, S., Jos, R., Kelly, O., Els, K., Tony, R., Nele, H., Nathalie, V., Yves, G., and Jan, C. (2011). The cellular redox state as a modulator in cadmium and copper responses in Arabidopsis thaliana seedlings. Journal of plant physiology 168, 309-316.

Das, P., Samantaray, S., and Rout, G. (1997). Studies on cadmium toxicity in plants: a review. Environmental pollution 98, 29-36.

De la Torre, F. R., Salibián, A., and Ferrari, L. (1999). Enzyme activities as biomarkers of freshwater pollution: Responses of fish branchial (Na+ K)-ATPase and liver transaminases. Environmental Toxicology: An International Journal 14, 313-319.

de Oliveira Mendes, G., de Freitas, A. L. M., Pereira, O. L., da Silva, I. R., Vassilev, N. B., and Costa, M. D. (2014). Mechanisms of phosphate solubilization by fungal isolates when exposed to different P sources. Annals of Microbiology 64, 239-249.

Deshwal, V. K., and Kumar, P. (2013). Effect of Heavy metals on Growth and PGPR activity of Pseudomonads. Journal of Academia and Industrial Research (JAIR) 2, 286.

Dixit, R., Malaviya, D., Pandiyan, K., Singh, U. B., Sahu, A., Shukla, R., Singh, B. P., Rai, J. P., Sharma, P. K., and Lade, H. (2015). Bioremediation of heavy metals from soil and aquatic environment: an overview of principles and criteria of fundamental processes. Sustainability 7, 2189-2212.

Dodd, I., Zinovkina, N., Safronova, V., and Belimov, A. (2010). Rhizobacterial mediation of plant hormone status. Annals of Applied Biology 157, 361-379.

Dubey, R. (2010). Metal toxicity, oxidative stress and antioxidative defense system in plants. Reactive oxygen species and antioxidants in higher plants 15, 177-203.

El-Meihy, R. M., Abou-Aly, H. E., Youssef, A. M., Tewfike, T. A., and El-Alkshar, E. A. (2019). Efficiency of heavy metals-tolerant plant growth promoting bacteria for alleviating heavy metals toxicity on sorghum. Environmental and Experimental Botany 162, 295-301.

[Citation: Nadeem, N., Asif, R., Ayyub, S., Salman, S., Shafique, F., Ali, Q., and Malik, A. (2020). Role of rhizobacteria in phytoremediation of heavy metals. Biol. Clin. Sci. Res. J., 2020: $35 . \quad$ doi: https://doi.org/10.54112/bcsrj.v2020i1.35] 
Etesami, H. (2018). Can interaction between silicon and plant growth promoting rhizobacteria benefit in alleviating abiotic and biotic stresses in crop plants? Agriculture, Ecosystems \& Environment 253, 98-112.

Falkowski, P. G., and Raven, J. A. (2013). "Aquatic photosynthesis," Princeton University Press.

Felix, H. (1997). Field trials for in situ decontamination of heavy metal polluted soils using crops of metal-accumulating plants. Zeitschrift für Pflanzenernährung und Bodenkunde 160, 525-529.

Gadd, G. M. (2000). Bioremedial potential of microbial mechanisms of metal mobilization and immobilization. Current opinion in biotechnology 11, 271-279.

Garrido, S., Del Campo, G. M., Esteller, M., Vaca, R., and Lugo, J. (2005). Heavy metals in soil treated with sewage sludge composting, their effect on yield and uptake of broad bean seeds (Vicia faba L.). Water, Air, and Soil Pollution 166, 303-319.

Gavrilescu, M. (2004). Removal of heavy metals from the environment by biosorption. Engineering in Life Sciences 4, 219-232.

Giordano, P., Mortvedt, J., and Mays, D. (1975). Effect of municipal wastes on crop yields and uptake of heavy metals. Journal of Environmental Quality 4, 394-399.

Glick, B. R. (2012). Plant growth-promoting bacteria: mechanisms and applications. Scientifica 2012.

Glick, B. R., and Stearns, J. C. (2011). Making phytoremediation work better: maximizing a plant's growth potential in the midst of adversity. International journal of phytoremediation 13, 4-16.

Goldstein, A. H. (1995). Recent progress in understanding the molecular genetics and biochemistry of calcium phosphate solubilization by gram negative bacteria. Biological Agriculture \& Horticulture 12, 185193.

González-Guerrero, M., Escudero, V., Saéz, Á., and Tejada-Jiménez, M. (2016). Transition metal transport in plants and associated endosymbionts: Arbuscular mycorrhizal fungi and rhizobia. Frontiers in plant science 7, 1088.

Grytsyuk, N., Arapis, G., Perepelyatnikova, L., Ivanova, T., and Vynograds' Ka, V. (2006). Heavy metals effects on forage crops yields and estimation of elements accumulation in plants as affected by soil. Science of the Total Environment 354, 224-231.

Guarino, F., Miranda, A., Castiglione, S., and Cicatelli, A. (2020). Arsenic phytovolatilization and epigenetic modifications in Arundo donax L. assisted by a PGPR consortium. Chemosphere 251, 126310.

Haas, D., and Défago, G. (2005). Biological control of soil-borne pathogens by fluorescent pseudomonads. Nature reviews microbiology 3, 307-319.

Halder, A., and Chakrabartty, P. (1993). Solubilization of inorganic phosphate byRhizobium. Folia microbiologica 38, 325330.

Hall, J. á. (2002). Cellular mechanisms for heavy metal detoxification and tolerance. Journal of experimental botany 53, 1-11.

Hansda, A., Kumar, V., Anshumali, A., and Usmani, Z. (2014). Phytoremediation of heavy metals contaminated soil using plant growth promoting rhizobacteria (PGPR): A current perspective. Recent Research in Science and Technology.

Hasan, S. A., Fariduddin, Q., Ali, B., Hayat, S., and Ahmad, A. (2009). Cadmium: toxicity and tolerance in plants. J Environ Biol 30, 165174.

He, Z.-1., and Yang, X.-e. (2007). Role of soil rhizobacteria in phytoremediation of heavy metal contaminated soils. Journal of Zhejiang University Science B 8, 192-207.

Henning, B., Snyman, H., and Aveling, T. (2001). Plant-soil interactions of sludge-borne heavy metals and the effect on maize (Zea mays L.) seedling growth. Water SA 27, 71-78.

Hontzeas, N., Hontzeas, C. E., and Glick, B. R. (2006). Reaction mechanisms of the bacterial enzyme 1-aminocyclopropane-1-carboxylate deaminase. Biotechnology advances 24, 420426.

Hou, W., Chen, X., Song, G., Wang, Q., and Chang, C. C. (2007). Effects of copper and cadmium on heavy metal polluted waterbody restoration by duckweed (Lemna minor). Plant physiology and biochemistry 45, 62-69.

Hughes, M. N., and Poole, R. K. (1989). "Metals and Micro-organisms," Chapman and Hall.

Hutchinson, T. (1973). Comparative studies of the toxicity of heavy metals to phytoplankton and their synergistic interactions. Water Quality Research Journal 8, 68-90.

[Citation: Nadeem, N., Asif, R., Ayyub, S., Salman, S., Shafique, F., Ali, Q., and Malik, A. (2020). Role of rhizobacteria in phytoremediation of heavy metals. Biol. Clin. Sci. Res. J., 2020: $35 . \quad$ doi: https://doi.org/10.54112/bcsrj.v2020i1.35] 
Iqra, L., Rashid, M. S., Ali, Q., Latif, I., and Malik, A. (2020). Evaluation for $\mathrm{Na}+\mathrm{K}+$ ratio under salt stress condition in wheat. Life Science Journal 17, 43-47.

Islam, F., Yasmeen, T., Arif, M. S., Riaz, M., Shahzad, S. M., Imran, Q., and Ali, I. (2016). Combined ability of chromium $(\mathrm{Cr})$ tolerant plant growth promoting bacteria (PGPB) and salicylic acid (SA) in attenuation of chromium stress in maize plants. Plant Physiology and Biochemistry 108, 456-467.

Jansen, E., Michels, M., Van Til, M., and Doelman, P. (1994). Effects of heavy metals in soil on microbial diversity and activity as shown by the sensitivity-resistance index, an ecologically relevant parameter. Biology and Fertility of soils 17, 177-184.

Jeevanantham, S., Saravanan, A., Hemavathy, R., Kumar, P. S., Yaashikaa, P., and Yuvaraj, D. (2019). Removal of toxic pollutants from water environment by phytoremediation: A survey on application and future prospects. Environmental Technology \& Innovation 13, 264-276.

Jia, Y.-J., Ito, H., Matsui, H., and HONMA, M. (2000). 1-aminocyclopropane-1-carboxylate (ACC) deaminase induced by ACC synthesized and accumulated in Penicillium citrinum intracellular spaces. Bioscience, biotechnology, and biochemistry 64, 299-305.

Joshi, P. M., and Juwarkar, A. A. (2009). In vivo studies to elucidate the role of extracellular polymeric substances from Azotobacter in immobilization of heavy metals. Environmental science \& technology 43, 58845889.

Karadede-Akin, H., and Ünlü, E. (2007). Heavy metal concentrations in water, sediment, fish and some benthic organisms from Tigris River, Turkey. Environmental Monitoring and Assessment 131, 323-337.

Khalid, S., Asghar, H. N., Akhtar, M. J., Aslam, A., and Zahir, Z. A. (2015). Biofortification of iron in chickpea by plant growth promoting rhizobacteria. Pak J Bot 47, 1191-1194.

Khalil, M., Rashid, M., Ali, Q., and Malik, A. (2020). Genetic Evaluation for Effects of Salt and Drought Stress on Growth Traits of Zea mays Seedlings. Genetics and Molecular Research 19.

Khan, A. A., Jilani, G., Akhtar, M. S., Naqvi, S. M. S., and Rasheed, M. (2009). Phosphorus solubilizing bacteria: occurrence, mechanisms and their role in crop production. $J$ agric biol sci 1, 48-58.

Khan, N., and Bano, A. (2018). Role of PGPR in the phytoremediation of heavy metals and crop growth under municipal wastewater irrigation. In "Phytoremediation", pp. 135-149. Springer.

Kloepper, J. W., Leong, J., Teintze, M., and Schroth, M. N. (1980). Enhanced plant growth by siderophores produced by plant growthpromoting rhizobacteria. Nature 286, 885-886.

Kong, Z., and Glick, B. R. (2017). The role of plant growth-promoting bacteria in metal phytoremediation. In "Advances in microbial physiology", Vol. 71, pp. 97-132. Elsevier.

Krantev, A., Yordanova, R., Janda, T., Szalai, G., and Popova, L. (2008). Treatment with salicylic acid decreases the effect of cadmium on photosynthesis in maize plants. Journal of plant physiology 165, 920-931.

Lahori, A. H., Zhang, Z., Guo, Z., Mahar, A., Li, R., Awasthi, M. K., Sial, T. A., Kumbhar, F., Wang, P., and Shen, F. (2017). Potential use of lime combined with additives on (im) mobilization and phytoavailability of heavy metals from $\mathrm{Pb} / \mathrm{Zn}$ smelter contaminated soils. Ecotoxicology and environmental safety 145, 313-323.

Lakra, N., Mishra, S., Singh, D., and Tomar, P. C. (2006). Exogenous putrescine effect on cation concentration in leaf of Brassica juncea seedlings subjected to $\mathrm{Cd}$ and $\mathrm{Pb}$ along with salinity stress. Journal of Environmental Biology 27, 263-269.

Lane, N., Allen, J. F., and Martin, W. (2010). How did LUCA make a living? Chemiosmosis in the origin of life. BioEssays 32, 271-280.

LeDuc, D. L., and Terry, N. (2005). Phytoremediation of toxic trace elements in soil and water. Journal of Industrial Microbiology and Biotechnology 32, 514-520.

Li, C., Zhou, K., Qin, W., Tian, C., Qi, M., Yan, X., and Han, W. (2019). A review on heavy metals contamination in soil: effects, sources, and remediation techniques. Soil and Sediment Contamination: An International Journal 28, 380-394.

Li, J.-F., He, X.-H., Li, H., Zheng, W.-J., Liu, J.-F., and Wang, M.-Y. (2015). Arbuscular mycorrhizal fungi increase growth and phenolics synthesis in Poncirus trifoliata under iron deficiency. Scientia horticulturae 183, 8792.

Liu, Y.-G., Xu, W.-H., Zeng, G.-M., Li, X., and Gao, H. (2006). Cr (VI) reduction by Bacillus sp.

[Citation: Nadeem, N., Asif, R., Ayyub, S., Salman, S., Shafique, F., Ali, Q., and Malik, A. (2020). Role of rhizobacteria in phytoremediation of heavy metals. Biol. Clin. Sci. Res. J., 2020: $35 . \quad$ doi: https://doi.org/10.54112/bcsrj.v2020i1.35] 
isolated from chromium landfill. Process Biochemistry 41, 1981-1986.

Liu, Z.-f., Ge, H.-g., Li, C., Zhao, Z.-p., Song, F.-m., and $\mathrm{Hu}, \quad \mathrm{S} .-\mathrm{b} . \quad$ (2015). Enhanced phytoextraction of heavy metals from contaminated soil by plant co-cropping associated with PGPR. Water, Air, \& Soil Pollution 226, 29.

Lugtenberg, B., and Kamilova, F. (2009). Plantgrowth-promoting rhizobacteria. Annual review of microbiology $63,541-556$.

Ma, W., Sebestianova, S. B., Sebestian, J., Burd, G. I., Guinel, F. C., and Glick, B. R. (2003). Prevalence of 1-aminocyclopropane-1carboxylate deaminase in Rhizobium spp. Antonie Van Leeuwenhoek 83, 285-291.

Ma, Y., Prasad, M., Rajkumar, M., and Freitas, H. (2011). Plant growth promoting rhizobacteria and endophytes accelerate phytoremediation of metalliferous soils. Biotechnology advances 29, 248-258.

Madhaiyan, M., Poonguzhali, S., and Sa, T. (2007). Characterization of 1-aminocyclopropane-1carboxylate (ACC) deaminase containing Methylobacterium oryzae and interactions with auxins and ACC regulation of ethylene in canola (Brassica campestris). Planta 226, 867876.

Marschener, H. (1998). Role of root growth, arbuscular mycorrhiza, and root exudates for the efficiency in nutrient acquisition. Field Crops Research 56, 203-207.

Marsh Jr, H., Evans, H., and Matrone, G. (1963). Investigations of the role of iron in chlorophyll metabolism I. Effect of iron deficiency on chlorophyll and heme content and on the activities of certain enzymes in leaves. Plant physiology 38, 632.

Martelli, A., Rousselet, E., Dycke, C., Bouron, A., and Moulis, J.-M. (2006). Cadmium toxicity in animal cells by interference with essential metals. Biochimie 88, 1807-1814.

Mazhar, R., Ilyas, N., Arshad, M., Khalid, A., and Hussain, M. (2020a). Isolation of Heavy Metal-Tolerant PGPR Strains and Amelioration of Chromium Effect in Wheat in Combination with Biochar. Iranian Journal of Science and Technology, Transactions A: Science 44, 1-12.

Mazhar, T., Ali, Q., and Malik, M. (2020b). Effects of salt and drought stress on growth traits of Zea mays seedlings. Life Science Journal 17.
McIntyre, T. (2003). Phytoremediation of heavy metals from soils. In "Phytoremediation", pp. 97-123. Springer.

Memon, A. R., Aktoprakligil, D., Özdemir, A., and Vertii, A. (2001). Heavy metal accumulation and detoxification mechanisms in plants. Turkish Journal of Botany 25, 111-121.

Mench, M., Schwitzguébel, J.-P., Schroeder, P., Bert, V., Gawronski, S., and Gupta, S. (2009). Assessment of successful experiments and limitations of phytotechnologies: contaminant uptake, detoxification and sequestration, and consequences for food safety. Environmental Science and Pollution Research 16, 876.

Mushtaq, Z., Asghar, H. N., and Zahir, Z. A. (2020). Comparative growth analysis of okra (Abelmoschus esculentus) in the presence of PGPR and press mud in chromium contaminated soil. Chemosphere 262, 127865.

Nadeem, S. M., Ahmad, M., Zahir, Z. A., Javaid, A., and Ashraf, M. (2014). The role of mycorrhizae and plant growth promoting rhizobacteria (PGPR) in improving crop productivity under stressful environments. Biotechnology advances 32, 429-448.

Nagajyoti, P. C., Lee, K. D., and Sreekanth, T. (2010). Heavy metals, occurrence and toxicity for plants: a review. Environmental chemistry letters 8, 199-216.

Nascimento, F. X., Rossi, M. J., Soares, C. R., McConkey, B. J., and Glick, B. R. (2014). New insights into 1-aminocyclopropane-1carboxylate (ACC) deaminase phylogeny, evolution and ecological significance. PLoS One 9, e99168.

Nie, L., Shah, S., Rashid, A., Burd, G. I., Dixon, D. G., and Glick, B. R. (2002). Phytoremediation of arsenate contaminated soil by transgenic canola and the plant growth-promoting bacterium Enterobacter cloacae CAL2. Plant Physiology and Biochemistry 40, 355-361.

Nouri, J., Khorasani, N., Lorestani, B., Karami, M., Hassani, A., and Yousefi, N. (2009). Accumulation of heavy metals in soil and uptake by plant species with phytoremediation potential. Environmental Earth Sciences 59, 315-323.

Ojuederie, O. B., and Babalola, O. O. (2017). Microbial and plant-assisted bioremediation of heavy metal polluted environments: a review. International journal of environmental research and public health 14, 1504.

Pajuelo, E., Rodríguez-Llorente, I. D., Lafuente, A., and Caviedes, M. Á. (2011). Legume-

[Citation: Nadeem, N., Asif, R., Ayyub, S., Salman, S., Shafique, F., Ali, Q., and Malik, A. (2020). Role of rhizobacteria in phytoremediation of heavy metals. Biol. Clin. Sci. Res. J., 2020: 35. doi: https://doi.org/10.54112/bcsrj.v2020i1.35] 
rhizobium symbioses as a tool for bioremediation of heavy metal polluted soils. In "Biomanagement of metal-contaminated soils", pp. 95-123. Springer.

Pamukcu, S., and Kenneth Wittle, J. (1992). Electrokinetic removal of selected heavy metals from soil. Environmental Progress 11, 241-250.

Persello-Cartieaux, F., Nussaume, L., and Robaglia, C. (2003). Tales from the underground: molecular plant-rhizobacteria interactions. Plant, Cell \& Environment 26, 189-199.

Pilon-Smits, E. (2005). Phytoremediation. Annu. Rev. Plant Biol. 56, 15-39.

Prasad, A., Kumar, S., Khaliq, A., and Pandey, A. (2011). Heavy metals and arbuscular mycorrhizal (AM) fungi can alter the yield and chemical composition of volatile oil of sweet basil (Ocimum basilicum L.). Biology and Fertility of Soils 47, 853.

Pratap, H., and Bonga, S. W. (1993). Effect of ambient and dietary cadmium on pavement cells, chloride cells, and $\mathrm{Na}+\mathrm{K}+-\mathrm{ATPase}$ activity in the gills of the freshwater teleost Oreochromis mossambicus at normal and high calcium levels in the ambient water. Aquatic Toxicology 26, 133-149.

Qi, G., Pan, Z., Sugawa, Y., Andriamanohiarisoamanana, F. J., Yamashiro, T., Iwasaki, M., Kawamoto, K., Ihara, I., and Umetsu, K. (2018). Comparative fertilizer properties of digestates from mesophilic and thermophilic anaerobic digestion of dairy manure: focusing on plant growth promoting bacteria (PGPB) and environmental risk. Journal of Material Cycles and Waste Management 20, 1448-1457.

Raffi, M., Mehrwan, S., Bhatti, T. M., Akhter, J. I., Hameed, A., Yawar, W., and ul Hasan, M. M. (2010). Investigations into the antibacterial behavior of copper nanoparticles against Escherichia coli. Annals of microbiology 60, 75-80.

Rahmaty, R., and Khara, J. (2011). Effects of vesicular arbuscular mycorrhiza Glomus intraradices on photosynthetic pigments, antioxidant enzymes, lipid peroxidation, and chromium accumulation in maize plants treated with chromium. Turkish Journal of Biology 35, 51-58.

Rajkumar, M., and Freitas, H. (2008). Influence of metal resistant-plant growth-promoting bacteria on the growth of Ricinus communis in soil contaminated with heavy metals. Chemosphere 71, 834-842.

Reichman, S. (2002). "The Responses of Plants to Metal Toxicity: A Review Forusing on Copper, Manganese \& Zinc," Australian Minerals \& Energy Environment Foundation Melbourne.

Requena, N., Jimenez, I., Toro, M., and Barea, J. (1997). Interactions between plant-growth-promoting rhizobacteria (PGPR), arbuscular mycorrhizal fungi and Rhizobium spp. in the rhizosphere of Anthyllis cytisoides, a model legume for revegetation in mediterranean semi-arid ecosystems. New Phytologist 136, 667-677.

Requena, N., Perez-Solis, E., Azcón-Aguilar, C., Jeffries, P., and Barea, J.-M. (2001). Management of indigenous plant-microbe symbioses aids restoration of desertified ecosystems. Applied and environmental microbiology 67, 495-498.

Ross, S. M. (1994). "Toxic metals in soil-plant systems," Wiley Chichester.

Saharan, B., and Nehra, V. (2011). Plant growth promoting rhizobacteria: a critical review. Life Sci Med Res 21, 30.

Saleem, M., Arshad, M., Hussain, S., and Bhatti, A. S. (2007). Perspective of plant growth promoting rhizobacteria (PGPR) containing ACC deaminase in stress agriculture. Journal of industrial microbiology \& biotechnology 34, 635-648.

Salt, D. E., Smith, R., and Raskin, I. (1998). Phytoremediation. Annual review of plant biology 49, 643-668.

Sayyed, R., Chincholkar, S., Reddy, M., Gangurde, N., and Patel, P. (2013). Siderophore producing PGPR for crop nutrition and phytopathogen suppression. In "Bacteria in Agrobiology: Disease Management", pp. 449471. Springer.

Schippers, B., Bakker, A. W., and Bakker, P. A. (1987). Interactions of deleterious and beneficial rhizosphere microorganisms and the effect of cropping practices. Annual review of Phytopathology 25, 339-358.

Schmidt, U. (2003). Enhancing phytoextraction: the effect of chemical soil manipulation on mobility, plant accumulation, and leaching of heavy metals. Journal of Environmental Quality 32, 1939-1954.

Schröder, P., Daubner, D., Maier, H., Neustifter, J., and Debus, R. (2008). Phytoremediation of organic xenobiotics-Glutathione dependent

[Citation: Nadeem, N., Asif, R., Ayyub, S., Salman, S., Shafique, F., Ali, Q., and Malik, A. (2020). Role of rhizobacteria in phytoremediation of heavy metals. Biol. Clin. Sci. Res. J., 2020: $35 . \quad$ doi: https://doi.org/10.54112/bcsrj.v2020i1.35] 
detoxification in Phragmites plants from European treatment sites. Bioresource technology 99, 7183-7191.

Schroth, M. N., and Hancock, J. G. (1982). Diseasesuppressive soil and root-colonizing bacteria. Science 216, 1376-1381.

Seregin, I., Shpigun, L., and Ivanov, V. (2004). Distribution and toxic effects of cadmium and lead on maize roots. Russian Journal of Plant Physiology 51, 525-533.

Sgroy, V., Cassán, F., Masciarelli, O., Del Papa, M. F., Lagares, A., and Luna, V. (2009). Isolation and characterization of endophytic plant growth-promoting (PGPB) or stress homeostasis-regulating (PSHB) bacteria associated to the halophyte Prosopis strombulifera. Applled microbiology and Biotechnology 85, 371-381.

Sharma, D., Sharma, C., and Tripathi, R. (2003). Phytotoxic lesions of chromium in maize. Chemosphere 51, 63-68.

Sher, S., and Rehman, A. (2019). Use of heavy metals resistant bacteria - a strategy for arsenic bioremediation. Applied microbiology and biotechnology 103, 6007-6021.

Silver, S., and Phung, L. T. (2005). A bacterial view of the periodic table: genes and proteins for toxic inorganic ions. Journal of Industrial Microbiology and Biotechnology 32, 587-605.

Singh, O., Labana, S., Pandey, G., Budhiraja, R., and Jain, R. (2003). Phytoremediation: an overview of metallic ion decontamination from soil. Applied microbiology and biotechnology 61, 405-412.

Singh, S. K., Singh, P. P., Gupta, A., Singh, A. K., and Keshri, J. (2019). Tolerance of heavy metal toxicity using PGPR strains of pseudomonas species. In "PGPR Amelioration in Sustainable Agriculture", pp. 239-252. Elsevier.

Tahir, M., Rashid, M., Ali, Q., and Malik, A. (2020). Evaluation of Genetic Variability in Wheat and Maize under Heavy Metal and Drought Stress. Genetics and Molecular Research 19.

Taj, Z. Z., and Rajkumar, M. (2016). Perspectives of plant growth-promoting actinomycetes in heavy metal phytoremediation. In "Plant Growth Promoting Actinobacteria", pp. 213231. Springer.

Tak, H. I., Ahmad, F., and Babalola, O. O. (2013). Advances in the application of plant growthpromoting rhizobacteria in phytoremediation of heavy metals. In "Reviews of
Environmental Contamination and Toxicology Volume 223", pp. 33-52. Springer.

Tank, N., and Saraf, M. (2009). Enhancement of plant growth and decontamination of nickel-spiked soil using PGPR. Journal of Basic Microbiology 49, 195-204.

Tanwir, K., Akram, M. S., Masood, S., Chaudhary, H. J., Lindberg, S., and Javed, M. T. (2015). Cadmium-induced rhizospheric $\mathrm{pH}$ dynamics modulated nutrient acquisition and physiological attributes of maize (Zea mays L.). Environmental Science and Pollution Research 22, 9193-9203.

Thomas, W. H., Hollibaugh, J. T., and Seibert, D. L. (1980). Effects of heavy metals on the morphology of some marine phytoplankton. Phycologia 19, 202-209.

Tirry, N., Joutey, N. T., Sayel, H., Kouchou, A., Bahafid, W., Asri, M., and El Ghachtouli, N. (2018). Screening of plant growth promoting traits in heavy metals resistant bacteria: prospects in phytoremediation. Journal of genetic engineering and biotechnology 16, 613-619.

Tiwari, K., Dwivedi, S., Singh, N., Rai, U., and Tripathi, R. (2009). Chromium (VI) induced phytotoxicity and oxidative stress in pea (Pisum sativum L.): biochemical changes and translocation of essential nutrients. J Environ Biol 30, 389-394.

Ullah, A., Heng, S., Munis, M. F. H., Fahad, S., and Yang, X. (2015). Phytoremediation of heavy metals assisted by plant growth promoting (PGP) bacteria: a review. Environmental and Experimental Botany 117, 28-40.

Unz, R. F., and Shuttleworth, K. L. (1996). Microbial mobilization and immobilization of heavy metals. Current Opinion in Biotechnology 7, 307-310.

Vacheron, J., Desbrosses, G., Bouffaud, M.-L., Touraine, B., Moënne-Loccoz, Y., Muller, D., Legendre, L., Wisniewski-Dyé, F., and Prigent-Combaret, C. (2013). Plant growthpromoting rhizobacteria and root system functioning. Frontiers in plant science 4, 356.

Van Loon, L. (2007). Plant responses to plant growth-promoting rhizobacteria. In "New perspectives and approaches in plant growthpromoting Rhizobacteria research", pp. 243254. Springer.

Van Loon, L., Bakker, P., and Pieterse, C. (1998). Systemic resistance induced by rhizosphere bacteria. Annual review of phytopathology 36, 453-483.

[Citation: Nadeem, N., Asif, R., Ayyub, S., Salman, S., Shafique, F., Ali, Q., and Malik, A. (2020). Role of rhizobacteria in phytoremediation of heavy metals. Biol. Clin. Sci. Res. J., 2020: $35 . \quad$ doi: https://doi.org/10.54112/bcsrj.v2020i1.35] 
Vessey, J. K. (2003). Plant growth promoting rhizobacteria as biofertilizers. Plant and soil 255, 571-586.

Viti, C., Pace, A., and Giovannetti, L. (2003). Characterization of $\mathrm{Cr}$ (VI)-resistant bacteria isolated from chromium-contaminated soil by tannery activity. Current Microbiology 46, 0001-0005.

Wang, Y.-T., and Shen, H. (1995). Bacterial reduction of hexavalent chromium. Journal of industrial microbiology 14, 159-163.

Wani, P. A., Zaidi, A., and Khan, M. S. (2009). Chromium reducing and plant growth promoting potential of Mesorhizobium species under chromium stress. Bioremediation journal 13, 121-129.

Wani, P. A., Zainab, I. O., Wasiu, I. A., and Jamiu, K. O. (2015). Chromium (VI) reduction by Streptococcus species isolated from the industrial area of Abeokuta, Ogun State, Nigeria. Research Journal of Microbiology 10, 66.

Watteau, F., and Berthelin, J. (1990). Iron solubilization by mycorrhizal fungi producing siderophores. Symbiosis.

Wuana, R. A., and Okieimen, F. E. (2011). Heavy metals in contaminated soils: a review of sources, chemistry, risks and best available strategies for remediation. Isrn Ecology 2011.

Xie, X., and Tang, M. (2019). Interactions between Phosphorus, Zinc and Iron Homeostasis in Non-mycorrhizal and Mycorrhizal Plants. Frontiers in plant science 10, 1172.

Zahran, H. H. (1999). Rhizobium-legume symbiosis and nitrogen fixation under severe conditions and in an arid climate. Microbiology and molecular biology reviews 63, 968-989.

Zaidi, A., Khan, M., Ahemad, M., and Oves, M. (2009). Plant growth promotion by phosphate solubilizing bacteria. Acta microbiologica et immunologica Hungarica 56, 263-284.

Zhao, F.-J., and McGrath, S. P. (2009). Biofortification and phytoremediation. Current opinion in plant biology 12, 373-380.

Zhu, D., Ouyang, L., Xu, Z., and Zhang, L. (2015). Rhizobacteria of Populus euphratica promoting plant growth against heavy metals. International journal of phytoremediation 17, 973-980.

Zubair, M., Shakir, M., Ali, Q., Rani, N., Fatima, N., Farooq, S., Shafiq, S., Kanwal, N., Ali, F., and Nasir, I. A. (2016). Rhizobacteria and phytoremediation of heavy metals.
Environmental Technology Reviews 5, 112119.

\section{(cc) (†) \&}

Open Access This article is licensed under a Creative Commons Attribution 4.0 International License, which permits use, sharing, adaptation, distribution and reproduction in any medium or format, as long as you give appropriate credit to the original author(s) and the source, provide a link to the Creative Commons licence, and indicate if changes were made. The images or other third party material in this article are included in the article's Creative Commons licence, unless indicated otherwise in a credit line to the material. If material is not included in the article's Creative Commons licence and your intended use is not permitted by statutory regulation or exceeds the permitted use, you will need to obtain permission directly from the copyright holder. To view a copy of this licence, visit http://creativecommons.org/licen ses/by/4.0/.

(C) The Author(s) 2021

[Citation: Nadeem, N., Asif, R., Ayyub, S., Salman, S., Shafique, F., Ali, Q., and Malik, A. (2020). Role of rhizobacteria in phytoremediation of heavy metals. Biol. Clin. Sci. Res. J., 2020: $35 . \quad$ doi: https://doi.org/10.54112/bcsrj.v2020i1.35] 